4th International Scientific Conference SEC-IASR 2019, Galati, Romania, 7th - 8th June, 2019

\title{
Aspects on Assessment Deontology of Teachers
}

\author{
Viorica - Torii CACIUC \\ https://doi.org/10.18662/lumproc/sec-iasr2019/09
}

How to cite: Caciuc, V.-T. (2020). Aspects on Assessment Deontology of Teachers. In S. Marin \& P. Moisescu (vol. eds.), Lumen Proceedings: Vol. 12. 4th International Scientific Conference SEC-LASR 2019 (pp. 74-83). Iasi, Romania: LUMEN Publishing House. https://doi.org/10.18662/lumproc/sec$\underline{\text { iasr2019/09 }}$ 


\title{
Aspects on Assessment Deontology of Teachers
}

\author{
Viorica - Torii CACIUC ${ }^{1 *}$
}

\begin{abstract}
In the context of the increase in the quality of the didactic act, the research on the report between the causes and the results which are activating the educational context, the reductionalist temptations and the ways of avoiding them, constitute a priority of the educational sciences. The quality of the didactic activity results, most of the time, from the competence with which the didactic staff manages to obtain good results which correspond to their settled goals, as part of organized and intentionally unfolded activities. The efficiency and efficaciousness with which a pedagogue manages to unify the three major activities of the educational process - teaching, learning and evaluation - do not reflect only the pedagogical competences and their skilfulness, but also their moral qualities. Thus some of the moral principles and values are reflected in the style of teaching, in ,the personal equation of the teacher", as a sign of subjectivism, from the act of evaluation, in the typology of the relationships he/she has with the pupils, with the parents or with the academic community that he/she belongs to. Besides the problem of the subjectivism of the evaluation and its moral connotations, we might mention some other aspects which can be associated directly or indirectly with the pedagogue's moral code. Their analysis imposes a deontological approach.
\end{abstract}

Keywords: deontology; competencies; continuous development; teacher evaluation; student evaluation.

\footnotetext{
1 PhD Associate Professor,Teacher Training Department "Dunărea de Jos" University of Galati, Romania, caciuca@yahoo.com 
Viorica - Torii CACIUC | Lumen Proceedings 12 | SEC-IASR 2019

\section{Introduction}

The increase in the quality of education is showing its effects on the evaluation, next to teaching and learning, either if it is about the measurement of the degree in which macro structural finality was achieved either if it is about the effects and the quality of the educative-instructive activity, as well as of the level of knowledge of students. The same importance has the fact that these results are dependent on the quality of teachers' didactic act. The contemporary educational context requires the formation of the professional competences at high standards for all the actors involved in this endeavour. And the results of the evaluation, regardless of its levels, are important to all the factors involved in the formation of the young generation of teachers. In this regard, it came the need to prepare a body of evaluators, which would contribute to an objective evaluation process for the teachers who participate in the final exam and in the contest for occupying the vacant posts.

The implementation of the continuous formation programme 'Formation programme for the development of evaluation competences of teachers for the final exam and the national contest for occupying the vacant posts', accredited and supplied by the Teachers' Staff House in Galati, constituted an excellent opportunity for the improvement of theoretical and practical preparation of teachers regarding the evaluation issues, through the implementation of the modules: Curricula and evaluation, Elaboration of instruments / evaluation subjects; The specific of evaluation in diverse situations: the final exam and the tenure exam; the specific of pedagogical evaluation in the context of written tests / vs. / oral ones; The evaluation of adults / vs. / the evaluation of students. Starting from these considerations, we would like to ameliorate the discrepancies between the attitudes of the evaluators reported to students, respectively to adults, in the case the junior teachers or those who wish to become holders of posts in general schooling. This is why respecting and developing of the values and professional ethics, which are part of the category of transversal competencies, should have an important place in the continuous formation programmes of teachers (to respect and to develop the values and the professional ethics, which are part of the transversal abilities, should occupy a significant place in the teachers' initial training programmes) [9].

\section{Problem Statement}

The divergences that are occurring during the evaluation and marking are due to the subjective dimension of the evaluating act, a 
dimension given by the personalities of the people involved in this process: the evaluating teacher and the evaluated teacher, directly, but also by some other factors, such as family, surroundings, or the context in which it takes place. The subjective factors of evaluation are determining two types of subjective influences: a positive, constructive influence, as a consequence of the subjective involvement of the evaluating and the evaluated teachers, guided by positive attitude and motivations, through which the capacity of subjects to spot what has significance to give sense to objective data is receiving value, named subjectivity and a negative, deforming influence, which produces errors, deviations from the objective character of evaluation, influence which can occur unintentionally - having its origin either in the competence level of the evaluator, either in the subjective effects that are accompanying 'naturally' the act of evaluation - or intentionally - having its origin either in the educational objectives of evaluation (the use of grades as stimulus / punishment for certain behaviour), either by using evaluation as means of favouritism / disadvantaging certain students (with implications in the area of morale and legality), named subjectivism [12]. The distinction between subjectivity and subjectivism has the role of understanding and identifying the contribution of the subjective factor in evaluation, and also of discovering efficient modalities to control the subjective influences on the evaluation process.

In the act of evaluation of teachers who are participating either in the tenure exam or the final exam, the subjectivity of the evaluating teacher might have pedagogical relevance, by giving the evaluative act a distinct meaning through his constructive contribution, which can give value to all the three levels: through its cognitive components, which means the ability of the subject to understand, explain, analyze and anticipate, to seize the essential in the multitude of concrete facts; through its affective motivational components, which means the subjective, energizing and directional employment, which is giving evaluation a significance of internal motivation, conduct factor, making evaluation an efficient means of directing and self-directing of behaviour; through the relational - attitudinal component, which means placing evaluation in the context of interpersonal relations between the evaluator and the evaluated, of the attitudes they have and show during the process of evaluation. [12].

Subjectivism is defined as 'negative manifestation of the subjective influences and it shows a greater interest than the positive side of the action of the subjective factor in the act of evaluation' [12]. The analysis of these negative manifestations of the subjective influences leads to the distinction between two types of influences: intentional and unintentional, both leading to errors and incorrect evaluative act. 
The unintentional subjective influences and effects are the most frequent in the process of evaluation, because evaluators do not intent to make an incorrect evaluation or to alter the results of the evaluation. Subjective errors in evaluation have the origins in the complexity of this activity, in the lower or higher degree of incertitude related to the appreciation of human qualities. Subjective distortions in evaluation can be grouped according to their specific causes, as follows: insufficient primary information according to which evaluation is conducted; inadequate means and methods of verification and evaluation in relation to the object of the evaluation (that is to be evaluated) and the objectives of the evaluation (the purpose of the evaluation); certain particularities of the direct relation between teacher and student, with its affective - attitudinal components; the direct influences of the psycho - social context in which evaluation is conducted (the position of the student's family, some indirect influences from the didactic staff, the school's board or the student's family); the influences of the pedagogical context in which the evaluation is taking place (the average level and the composition of the class, some elements from the school's policy regarding evaluation, such as reaching a certain percentage of graduates, stimulating success or lowering failures etc.) [12].

The imperfections or the errors in evaluation are representing the effects of the unintentional manifestation of subjectivism in evaluation, bearing a cognitive significance and not a moral one. Control and selfcontrol, together with a better knowledge and application of the methods and techniques of evaluation are representing modalities of diminishing and amelioration of errors in this category.

The intentional intervention of subjective influences has a complex causality, including social and moral implications. Given the context in which the teacher is intentionally modifying (amplifies or lowers) the results in the act of evaluation, two typical situations can be identified: the first one is that when evaluation and especially grading are used as a means of stimulation / punish with a pedagogical function, in directing the learning behaviour of students - situation in which the teacher's evaluations can stray in one way or another from the real level of the students', and the other one is that when the alteration of evaluation is taking place intentionally in order to give advantage (or disadvantage) to some students, following extrapedagogical criteria, having social and moral connotations, being associated to the teacher's moral conduct. [12].

All these are leading to the idea that teacher's objectivity during evaluation is based on the idea of impartiality, as a form of manifestation of the educator's morality in the course of the evaluating act. In this sense, the idea of impartiality that stands at the base of all the theories on morality 
states that 'everyone's interests are equally important: from the moral point of view, there are no privileged persons, everyone's life has the same value [10: 17]. This would mean that to the evaluating teacher, all the evaluated teachers have the same importance, the welfare of each candidate is equally important. This request of impartiality refers to, in the same time, the elimination of any scheme "which treats the members of disadvantaged groups as being somehow inferior from the moral point of view' [10: 17] such as substitute teachers from the rural schools or from special schooling environments. The evaluator's moral judgements need to be supported by good reason in order to avoid discrimination of the candidates during the process of evaluation. In this way, the request of impartiality should apply as a rule that forbids the evaluators to treat a teacher in a 'different' manner if there are no strong reasons to do that, by giving in the same time equal value to the interests of each candidate, in the effort to guide their moral conduct. Respecting the criteria of impartiality means that in his relation to the teachers, the evaluator should address them 'always as the scope and never as the means' [5: 237]. In this way, through this perspective, the evaluated teachers are representing the scope of the activity of the evaluating teachers, which means that the evaluator's duty towards the evaluated teachers is promoting their well-being, respecting their rights, avoiding harming them, generally contributing to the fulfilment of their scopes. [10: 127]

\section{Research Questions/Aims of the research}

Starting from these considerations, I have started to do an investigation which will reflect the vision of the teachers on the errors that are occurring during the evaluation of teachers, my research trying to contribute to the change of perception towards the acts of respect or disrespect for the professional deontology. The hypotheses of this research were: What are the teachers' representations regarding respecting or breaking the professional deontology in the context of evaluating adults compared to evaluating students? The objectives of the research are: 1 . To determine the perception of teachers on the deontology of didactic profession: the deontology of evaluation, subjectivity versus subjectivism; 2 . To identify suggestions, recommendations, proposals, solutions for the deontological formation of teachers; 3 . To highlight the effects produced by the deontological formation of teachers by going through some continuous formation programmes, one of our previous preoccupations[1],[2]. 


\section{Research Methods}

Taking into consideration that 'focus groups are working best for determining points of view, feelings and opinions of people regarding different problems, goods, services or opportunities' [6: 29], we have organised our 110 students in groups of 25-28, using some criteria: to be specialised in the same object, to have the same rank (1st or 2nd didactic rank), to be methodologist teachers or principals, or none of the latest.The problems studied or put into discussion in the focus groups were related to subjectivity versus subjectivism in the process of evaluation of students, as well as in the process of evaluating teachers and the deontology of evaluation, such as: the use of evaluation as a mean of punishment or disciplinary, the high pace of formative evaluation as a mean to obtain feedback for the activity of teaching-learning at class level, but also at teachers' level, especially of those who applied for the definitive exam, the use of evaluation for the motivation or de-motivation of the student, respectively of the teachers, especially of the debutants, the constant care of the teacher to stimulate the investigative spirit of students/teachers, to encourage the knowledge gain, understanding and developing of personal scopes, but also to value evaluation as a mean of punishment or motivation for teachers, availability to council debutants, the higher level of severity towards students or towards teachers. I have proposed for discussion a series of dilemmas, such as: you are a member in the commission for speciality inspections and implicitly for personal portfolios and the following happens: 1 . To be in the commission with a colleague having the attitude of 'master' teacher [11] in the evaluation for his object, and as a consequence of this the candidate if nervous, not knowing what attitude to use during his activities, but especially when it comes to self-analysis and analysis of his activities; 2 . To be in a commission with a colleague who has his own vision regarding 'the perfect teacher' [11] showing much severity in the evaluation of the debutant teacher, sanctioning heavily any mistake noticed; 3 . To be in a commission with a colleague who has an indulgent attitude towards the evaluated teacher, considering only the presentation of the materials from the professional portfolio as sufficient. How do you proceed in order to obtain an objective evaluation?

The analysis of the activity's outcomes allowed completing the information of the research, because through these outcomes that are included in their evaluation portfolio it was proven that this formation course contributed to solving some problems identified in the evaluation of teachers, such as subjectivity, respectively unintentional subjectivism. This way, the comparative analysis of the programmes for preparation of 
definitive or tenure exams, as well as the elaboration of tests and their standards, together with the evaluation matrix, the analysis of tests and standards from previous years in order to identify the situations of subjectivity, respectively subjectivism that are present in them, reflexive essays on the attitude of the evaluator, the elaboration of certain criteria for marking during the evaluation of the professional portfolio of the teacher, according to annex 14 to the Frame - Methodology for organising and development of the national examination for definitive posts in education (2018), the structure of which is showed in Section 3, art.16, line (3) [8].

\section{Discussions}

Starting from these considerations, the style of the 'master' teacher, all the subjects have considered that is was a violation of the evaluation deontology by that colleague we mentioned earlier, but most of them, $90 \%$, mentioned that they would try to make more detailed observations during their courses, in order to identify the positive aspects of the activities and would intervene with helping questions, in order to guide the debutant teacher how to handle the stress, while $5 \%$ mentioned that they would support their colleague, if the debutant teacher would be unprepared, and the other $5 \%$ said that they would address the superiors, especially if the evaluation process would not be objective.

In the situation of orientation by the fictive model of the 'perfect' teacher, all the subjects have appreciated that this situation represented a violation of the deontology of evaluation, and in regard of the modality of helping the debutant teacher, $85 \%$ of the subjects mentioned that they would make observations as correct as possible and would support and encourage the evaluated teacher, and $15 \%$ mentioned that a teacher should tend to achieve perfection and they would support their colleague, only if he evaluated in a correct manner. All the subjects have disagreed with the evaluation of a candidate based only on the simple presentation of the materials from his personal portfolio, without taking into account the correctness and authenticity of the portfolio's elaboration. They have all brought into discussion the fact that an evaluating teacher should prove honesty, respect, and responsibility for the training of the new generations of teachers. In this sense, Daniela Jeder considers that 'the value of moral responsibility is in the attention of teachers, as much as they are responsible for the responsibility of those they are educating' [4: 75], [7], highlighting the training role of the evaluating teachers.

Given the fact that the intrigue of these activities was the evaluating grid for the personal portfolio, we asked the subjects to establish a set of 
grading criteria, which would constitute a guide for the diminishing of subjectivity, respectively subjectivism, in the process of evaluation of the young generations of teachers. Out of those, with a higher frequency there were: an annual planning and on the integrated unit of learning, an idea supported not only by the teachers from primary school but also by the teachers from secondary school, because they have often observed children being overloaded or the presence of certain confusions in the study of a subject, based on the learnings from another subject (such as physics and mathematics, foreign languages and Romanian Language), the correctness of didactic projection, starting from the correct selection of the specific competences, the correctness of derivation and operationalization of the operational objectives of the lesson, the appropriate processing of the contents and their presentation in the project, the respect for the lesson's links, the right appraisal of the strategies and didactic materials and the highlight of the evaluative aspects, all of these adapted to the classes specificity; the dosing of the effort for learning and of the learning resources, planned correctly; the highlight of the modalities for diminishing subjectivism in evaluation, reflected in the documents for school progress measurement, as well as the diminishing of school unsuccessful by applying the recovery measures we have presented. Another aspect highlighted by the subjects was the degree of objectivity in the candidate's self-evaluation, but also the impossibility to verify the degree of plagiarism of the portfolio. All the subjects have agreed on the fact that it is mandatory that the pieces be present in the portfolio and, as a consequence, the grades need to be given according to the correctness of the elaboration of the portfolio. They have all appreciated the utility of this kind of exercise, in the context in which this information is not presented in the methodology for organising the definitive examinations.

\section{Conclusions}

The development of some projects for training teachers in parallel with the implementation of some reforms and changes in the educational policies has became a practice in the Romanian teaching system. This fact represents an advantage, because it creates a body of experts that are well formed in the field of the respective change, in this case the change targeting the definitive and tenure exams, as well as in the same time solving the problems generated by the change, but also a disadvantage because it creates a bad habit of implementing educational policies without foreseeing, through the necessary documents, the systematic and continuous character of the projected changes. In the situation of this project, the learning activities led 
to the formation of a group of experts in evaluation, who will be able to make an objective evaluation of the young generation of teachers. I would recommend that the module regarding the deontology of the didactic profession be a part of some other training courses, because the process of interiorising of values and ethical virtues is a complex one and it takes time, and on the other hand all these can be applied in other contexts of the instructive-educative process.

"Practice of education and training provides numerous examples of ethical risk, which, in most cases, have as victim children / students. Teacher's training, both initial and continuous, should therefore need to set as priority training the ethical, moral dimension of the personalities of those who carry out education - the teachers. We invoke here the strategies of reflection on the ethical behaviours of all those involved in school activities, knowing that each influences, shapes, form." [3: 435].

\section{References}

[1] Caciuc VT. Interdisciplinary Perspectives of Ethical Training of Prospective Teachers.In Sandu A, Frunză A, editors. Rethinking Social Action. Core Values. Bologna: MEDIMOND Publishing Company; 2015.pp .203-2016.

[2] Caciuc VT. The Role of Virtue Ethics in the Deontological Training of Prospective Teachers. In Sandu A, Frunză A, editors.Logos Universality Mentality Education Novelty. Section: Social Sciences. Year III. Issue 1.Iaşi. Lumen Publishing House. pp. 47-56.

[3] Jeder D. Teachers' Ethic Responsibilities in the Practice of Education and Training.Procedia - Social and Behavioral Sciences. 2013; 92:432-436.

[4] Jeder D. Valori etice în discursul educational .In Sandu A, Popoveniuc B. (coord). Etică şi integritate în educație şi cercetare .Bucureşti: Editura Tritonic; 2018. pp. 67-109.

[5] Kant I. Intemeierea metafizicii moravurilor .In Kant I. Critica rațiunii practice.Bucureşti:Editura IRI; 1995.

[6] Krueger RA, Casey MA.Metoda focus grup: ghid practice pentru cercetarea aplicată Iaşi: Editura Polirom; 2005.

[7] LévinasE. Întrenoi. Încercarea de a-l gândipeCelîlalt, Bucureşti:Editura ALL; 2000.

[8] Ministerul Educației Naţionale (MEN). Metodologia - cadru de organizare şi desfăşurarea examenului național de definitivare în învăţământ (2018). Anexa la OMEN nr. 5211/02.10.2018. Available from: http://definitivat.edu.ro/2019/docs/Metodologie\%20si\%20anexe\%20MO.pdf

[9] Program de formare privind dezvoltarea competențelor de evaluare a cadrelor didactice pentru examenul de definitivat şi concursul naţional pentru ocuparea 
posturilor vacante, Furnizor program formare acreditat: Casa Corpului Didactic Galați, Nr. OM de acreditare/data: 5990/16.12.2015.

[10] Rachels J. Introducere în etică. Bucureşti: Editura Punct; 2000.

[11] Voiculescu E. Evaluarea şcolară şi deontologia profesiunii didactice. In Ionescu M, Chiş V. (coord.). Studii de pedagogie. Omagiu profesorului Dumitru Salade. Cluj-Napoca: Editura Presa Universitară Clujeană; 2000.pp.181-189.

[12] Voiculescu E. Factorii subiectivi ai evaluării şcolare. Cunoaştere şi control, Bucureşti: Editura Aramis; 2001. 